\title{
Diglossia as Ideology
}

\author{
Kristen Brustad
}

\section{Introduction}

The Language Change in the Arab World (LCAW) project evolved from the collective sense of the researchers involved that there appears to be a significant shift underway in writing practices and attitudes toward writing in the Arab world. This paper proposes a framework for the study of attitudes toward writing in non-standard Arabic, and applies this framework to data from a Twitter hashtag about writing in Arabic, and to the results of the 2013 and 2015 FAFO surveys of language attitudes and society in Cairo and Rabat (Kebede, Kindt and Høigilt 2013, Kebede and Kindt 2016).

This framework takes as a fundamental principle that language does not preexist usage, but rather is constantly being constructed and reconstructed by its users. In other words, categories such as register exist insofar as speakers imagine and create them. Informing these practices is a shared set of ideas about language use, which linguistic anthropologists call "language ideology."1 These concepts may be articulated or not, conscious or not, and while they represent an important aspect of the culture of the language, they do not necessarily reflect linguistic practice. I will argue here that diglossia is such a linguistic ideology. The split in registers between fuṣhā and 'âmmiyya is real for Arabic speakers as an idea about what Arabic is or should be. However, diglossia does not serve us well as a tool of linguistic analysis.

In this essay, I follow the LCAw terminology in using the terms fuṣhā and 'âmmiyya/dārija ${ }^{2}$ as conventions, although I argue that the binary construct they reflect is an ideological one. The terms standard and non-standard also reflect a binary, but perhaps a less ideologically-charged one, and they are used

1 Language ideology refers to shared cultural beliefs that underlie language usage, beliefs that are taken by most speakers as the natural state of affairs. The concept differs from political ideology, which refers to a set of consciously held convictions. Language ideology, on the other hand, refers to beliefs about language that speakers assume to be given, "natural" (see further Schieffelin et al. 1998; Milroy 1995; Irvine and Gal 2000).

2 In this paper I discuss both Egyptian and Moroccan spoken Arabic, and follow the conventions of using 'àmmiyya to refer to Egyptian spoken Arabic and dārija to refer to Moroccan. 
herein as synonyms for fuṣhā and 'ammmiyya. However, the use of these terms as analytical tools is necessary here because we as yet lack an alternative set of analytical terminology. It is hoped that further study of variation in written and spoken Arabic will evolve more nuanced terms for register and style use, because it is increasingly clear that the distinction between written and oral, formal and informal modes of communication is more ideal than practice, and perhaps always was. The present paper is meant to encourage such studies.

The diglossic nature of Arabic as postulated by Ferguson 1959 can no longer be maintained as description of linguistic reality. As Mejdell (2016) demonstrates, this imagined boundary is "erased" and "crossed" deliberately by contemporary writers; Doss and Davies (2013) for Egypt and Lentin and Grand'Henry (2008) for Levantine show that this has been going on for centuries. We cannot know the scope of such "border crossings" just as we cannot know the reality of writing across society by the accident of what survives today, since most of it has been "corrected" by editors to adhere to contemporary norms before publication. Fuṣha as an ideal was promoted and protected vigorously in the twentieth century, but now, with new technologies of writing and ensuing democracies of expression, this ideal has come under increasing pressure. This may be seen clearly in the rhetoric of "Arabic in Danger" that is the topic of many television shows, newspaper articles, and conferences. ${ }^{3}$ This rhetoric reflects an urgent sense that Arabic has lost or is losing something. I argue here that what it seems to be losing, and what is really at stake at present, is its existence as an idealized language with special status.

This argument follows and reframes the observation made by Madiha Doss that "the evolutions we are witnessing today in language use are closely linked to attitudinal change" (2006:52). We will explore this attitudinal change in the framework of Standard Language Ideology as Milroy (2001) theorizes it. We will also examine the attitudes of speakers and writers of Arabic as examined in the LCAW surveys and the Twitter hashtag بكتب_بالعربي,\#, \#I_write_in_Arabic. This hashtag, which was launched in conjunction with International Arabic Day in 2014, constitutes an ideological site, a metalinguistic discussion on Arabic. Twitter feed is one of several public platforms that affords both access and forum for public comment; that is, both writing and the evaluation of it by other users are available for analysis. The interactive nature of this writing technology has many implications that I hope to explore elsewhere.

3 See for example the Al-Jazeera program titled حماية اللغة العربية hosted by Faisal Qasim on the series الاتجاه المعاكس. 


\section{Variation in the History of Written Arabic}

It is axiomatic in the field of Arabic that the grammar and standards of fuṣha have changed little in the past 1400 years. Charles Ferguson built his theory of diglossia in part on this assumption, and the entire sub-field of Middle Arabic likewise originated in the notion that non-standard pre-modern writing was exceptional and thus worth of study in and of itself. But the work of many scholars of Middle Arabic, including studies by Blau (2002), Doss and Davies (2013), and Lentin (2008, 2009), as well as Zack and Schippers (2012), points clearly to the fact that a significant number of highly educated and talented elite did not feel constrained to write in what we now call fuṣhă. Lentin argues that "Middle Arabic was an instrument of communication in many fields of social and cultural life" and is thus to be seen as a register in its own right (2008:218). Hopkins' (1984) study of the earliest Islamic-era Arabic papyri shows that variation in written Arabic goes back to the very beginning of its recorded history as we currently define it; in fact, that recorded history is rapidly expanding into the early centuries of the Common Era (see e.g. AlJallad 2015). It seems that the existence of non-standard varieties has been as stable as that of the standard (ideal) language; if so, it is precisely the stability of the language as a whole that is linguistically interesting. It is particularly noteworthy that the Arabic script itself, with its lack of short vowels - which represent precisely the kinds of variation that have characterized varieties and registers of Arabic for centuries - may have developed and been maintained in part to admit the variation that we still see today.

The 2013 publication of Written Egyptian Arabic العامية المصرية المكتوبة by Madiha Doss and Humphrey Davies represents a relatively recent insight in the field that we should treat non-standard written Arabic as part of the written record, and not as a collection of errors. The book traces a six-hundred year history of literary production in Egypt that consciously and unapologetically uses 'ämmiyya. Such studies are of utmost importance in putting the current increased production of 'ämmiyya texts into historical perspective. As Doss notes, "one should start by observing that the trend of writing in colloquial has a very long tradition, dating back to the $15^{\text {th }}$ century, and that it follows a rising and falling curve at different times according to social and historical factors which should be studied for each period." (2006:54).

We may only just be beginning to scratch the surface of writings that do not hold to the standards of fuṣha as we currently envision them. Nelly Hanna's (2003) study of the reading and writing practices of an emergent middle-class in 16th to 18th century Cairo points to the existence of a significant practice of writing in an unstandardized idiom. Examining archives of private libraries in 
Cairo from the 16th to the 18th centuries, she finds that a Cairene "middle class" was reading and writing on a much larger scale than previously thought, and doing so in a language that did not always adhere to the rules of the standard (2003:157-158).

There are well-known experiments with writing in non-standard Arabic during the nahda, such as 'Abdallah Nadim's journal al-Ustāz; less well-known are examples such as the following letter, in which a figure no less than the "Mu'allim" himself, Butrus al-Bustani (d. 1883), author of an important nahdaera grammar, permitted himself to use several non-standard expressions,

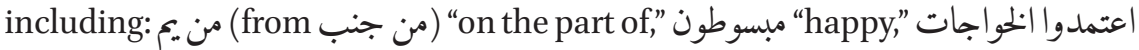
"the foreigners decided to," and تطني "reassure me" (see figure 2.1, reproduced from Dayeh 1984:180)

Butrus al-Bustani was deeply involved in the promoting of classical Arabic, and there is no doubt of his mastery of it. Therefore, these cannot be dismissed as 'mistakes.' Rather, they are an integral part of a complex communicative act in which al-Bustani conveys aspects of his personal relationship with his addressee while maintaining the decorum of a written letter. Findings such as this demonstrate the need for an analytical framework that takes style and communicative exigencies - which sometimes compete within the same space - into account.

Moreover, as Lentin points out (2011, section 2), our perception of the history of written Arabic is colored not just by the few manuscripts that have survived, but also by the fact that it has been standard practice since the 19th century to "correct" them to the standards of fușhā. The use of print technology to publish manuscripts allowed the editing or "correction" of manuscripts before publishing so that they fit expectations, which promoted the erasure ${ }^{4}$ of language variation that may have existed in pre-modern times, and that was easily attributable to error-prone copyists. Our perspective on the past has been shaped by this prism, including a very active system of "language correction" (further below). When we add to that the cost of publishing and the fact that many attempts to launch non-government papers and series ended in failure within a year or two, we are reminded that access to public writing was very tightly controlled and standardization relatively easy to establish and maintain, if in fact the elite wished to do so. ${ }^{5}$

4 On the sociolinguistic process of erasure, the process by which certain linguistic phenomena get "erased" from our view so that we do not see or hear them and do not have to take account of them, see Irvine and Gal 2000.

5 The 1881-1882 discussions in al-Muqtataf show that they did. An editorial pondering the most effective language to use in helping to spread learning among the masses presented āmmiyya 


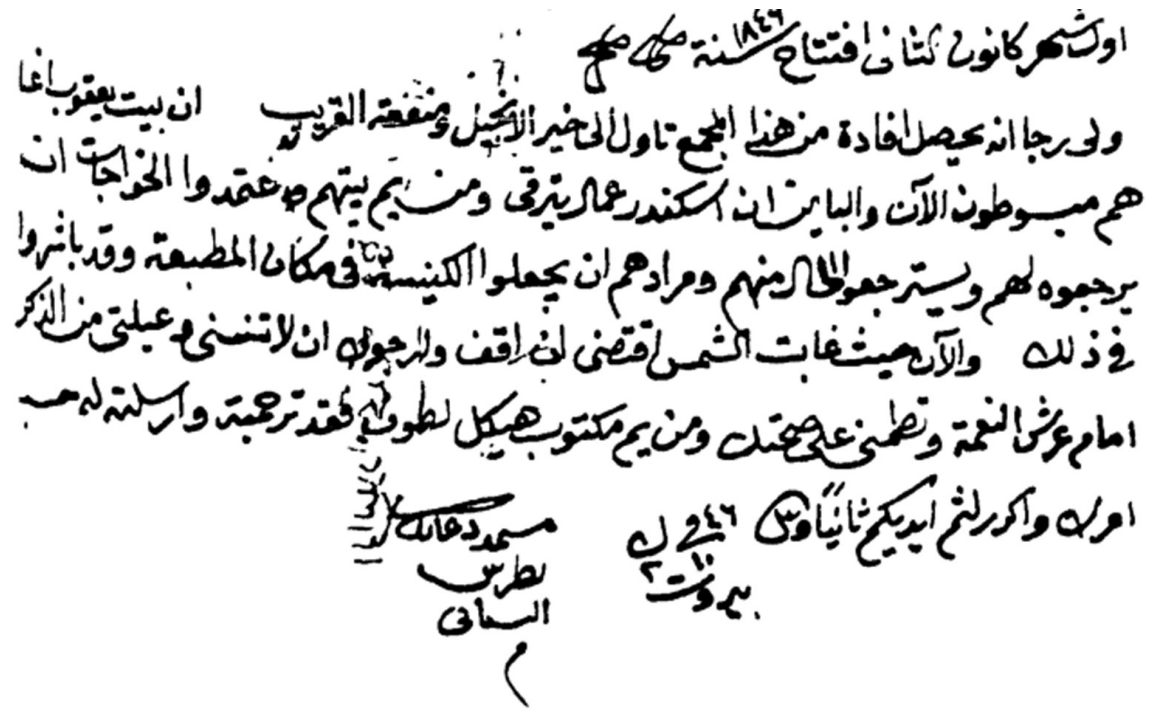

FIGURE 2.1 Letter by Butrus al-Bustani

$$
\begin{aligned}
& \text { أول شهر كانون الثاني افتتاح سنة } 1846 \\
& \text { ولي رجا أنه يحصل افادة من هذا المجمع تاول الى خير الانجيل ومنفعة القريب ان } \\
& \text { بيت يعقوب اغا هم مبسوطون الآن والباين ان اسكندر عمال يترقى ومن يمّ بيتهم اعتمدوا } \\
& \text { الخواجات انيرجعوه لمم ويسترجعوا المال منهم ومر ادهم ان يبجعلوا الكنيسة في مكان المطبعة } \\
& \text { وقد باشروا في ذلك والآن حيث غابت الشمس اقتضى ان اقف وارجوك ان لا تنسني وعيلتي } \\
& \text { من الذكر امام عرش النعمة وتطمني على صحتك ومن يم مكتوب هيكل لطوف فقد تربمته }
\end{aligned}
$$

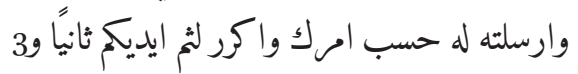

$$
\begin{aligned}
& 46 \text { في } 10 \text { كانون } 2 \text { بيروت } \\
& \text { بطرس البستاني }
\end{aligned}
$$

It appears, then, that the history of "fuṣh $\bar{a}$-only" writing may not have been as long or pervasive as has largely been assumed. We view what is happening now as something new and different, but there is another viewpoint we should

as a possible alternative (1881: no. 6). This set off a virulent series of exchanges that took the discussion in another direction - that of maintaining fuṣ ha to the exclusion of all else, for reasons that had little to do with educational needs. 
consider: that the 2oth century is an aberration in the long history of Arabic. By the beginning of the twentieth century, the late nahda language experiments meant to further ambitious social projects educating the masses had begun to narrow considerably, and the educated elite reasserted their authority over written language. ${ }^{6}$ Effectively, what Twitter and other internet technologies are now doing is opening up spaces in which the language corrector and editor have no control, so that it is much more difficult for non-standard writing to be 'erased' from public consciousness.

All this makes the framework of diglossia inadequate to explain and analyze all linguistic practice, not only in the present, but also for the past. In the following section, I will argue that diglossia functions better as a description of a language ideology than of a linguistic reality.

\section{Standard Language Ideology}

The roots of the terms fușhāand 'ämmiyya, guage (see Ayoub 2011) and $\rho$ ع referring to non-elite groups, appear to date back to the ninth century $\mathrm{CE}$, but their widespread use in the sense we understand them today seems to be related to the term and concept of diglossia, which emerged from the nahda, though it was not theorized until Ferguson published his well-known 1959 treatise. Briefly, Ferguson postulated that a certain kind of linguistic community could be described as diglossic: characterized by the existence of two linguistically distinct and functionally separate registers, High $(\mathrm{H})$ and Low $(\mathrm{L})$, whose distance was maintained through their use in separate spheres, and the existence of a rich literary tradition in the $\mathrm{H}$ register that enriched it. Finally, he noted that diglossic communities tended also to be marked by widespread illiteracy. Ferguson is not alone in claiming the long stability of $\mathrm{H}$ in Arabic; he merely echoes the tradition itself. These concepts and terms have taken the lead in framing discussions of Arabic in the modern period.

However, Ferguson himself tells us, through the language he uses, that diglossia describes an ideology. Certain words he repeatedly employs already

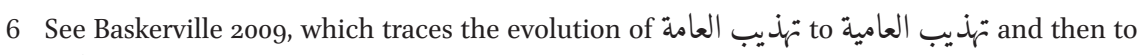
- مهميش العامية - and with it any project to educated the lower classes. The discussion in alMuqtataf 1881-1882 shows the same pattern in condensed form: a proposal to adopt language to make education more accessible degenerates into acrimonious arguments over Arabic; in the end, those who expressed positive attitudes toward using spoken forms of Arabic are silenced. 
point us in the direction of language ideology: "Sometimes the feeling is so strong that $\mathrm{H}$ alone is regarded as real and $\mathrm{L}$ is reported 'not to exist'" ... "Even where the feeling of the reality and superiority of $\mathrm{H}$ is not so strong, there is usually a belief that $\mathrm{H}$ is somehow more beautiful, more logical, better to express important thoughts, and the like. And this belief is held also by speakers whose command of $\mathrm{H}$ is quite limited" (1959:329-330; emphasis mine). In using words like "feeling," "belief," and "regarded as," Ferguson himself indicates what we now call language ideology (a term that did not exist during his career). It is not that $\mathrm{H}$ is superior to $\mathrm{L}$ or more real or beautiful, but that the speakers of this culture feel and believe that it is - even those for whom $\mathrm{H}$ is not part of their daily lives. In other words, it is a shared belief among all members of this culture. This is the core of language ideology.

Moreover, it is likely that the ideology of diglossia itself has helped engender a sociolinguistic process of erasure that renders mixed or 'ammmiyya texts invisible. In other words, the ideology of diglossia leads us to expect written texts in fuṣha and to see them as normative; the texts that do not fit the model are brushed off, or, in the nahda and 2oth century, physically erased, either through the 'correction' process or exclusion from publishing.

The phenomena noted by Ferguson and described as diglossia align very closely with what Milroy calls Standard Language Ideology, which, we should note, he developed to explain certain patterns of linguistic thought and behavior in Britain, not considered by Ferguson to be a 'diglossic' language community. Milroy defines a standard language ideology culture as one in which speakers believe their language exists in "a clearly delimited perfectly uniform and perfectly stable variety - a variety that is never perfectly and consistently realized in spoken use" (2001:542, emphasis original). When two or more forms exist, only one is correct.

The framework of standard language ideology allows us to go beyond analyzing Arabic as an H/L binary, and helps us understand the cultural constructs behind the binary terms. In the context of Arab history and culture, including the strong ties between fuṣha $\bar{a}$, the Qur'an and the prophet Muhammad, standard language ideology idealizes fuṣhā beyond its 'correctness' to a moral stature that, at its logical extreme, makes any language form that is not fuṣha a moral failing. This is precisely what happened during the nahda when the establishment of state institutions, and eventually Arabic Language Academies, helped ensure that the view of what fuṣhā comprised grew increasingly more narrow as time passed. Thus, for example, the disappearance of the verb 1 from formal Arabic in the twentieth century - despite its use by someone like Taha Hussein - should probably be seen as a result of its prevalence in spoken Arabic, not its inherent inappropriateness for writing. 
The ideology of the standard became so strong in the twentieth century that reform projects collapsed under its weight. ${ }^{7}$ For reasons that deserve further study (but must involve language ideology, class struggle and upheavals in the education system), there arose early in the 19oos an idea that written Arabic was not accessible to pupils and to the population at large. Something had to be done to make written Arabic more accessible, and some focused on the alphabet as the problem. One possible motivation for this would be that changing the alphabet only would allow the language itself to remain intact, as the culture of standard language ideology - and the sociopolitical interests it served - dictated. Calls to reform the Arabic writing system reached their peak from 1944 to 1947, when the Arabic Language Academy in Cairo put forth a call for proposals for the simplification of the Arabic writing system. In response, 84 projects were proposed to the Academy, but not a single one was chosen to receive the prize (Khattar 1972:6). The fact that no prizes were awarded demonstrates clearly that this project was doomed from the beginning.

The Arabic language academies were institutions whose very existence we can attribute to the attempts to maintain standard language ideology. Their primary goals were to guard the Arabic language from corruption and decay and modernize it. It is their existence, and not their accomplishments, that people point to as important for the preservation of Arabic, and this points to their role in maintaining standard language ideology. Arabic Language Academies are bound by this ideology, and this is why they are all but incapable of taking action.

What is happening now on social media and the internet stands in stark contrast to the attempt to overhaul the writing system of Arabic some 70 years ago. The use of Latin letters to write Arabic, called 'Franco,' appears to solve the difficulty of the Arabic script. In the following exchange on a social forum called 'Fatakat,' we find some metalinguistic commentary on the use of this script (http://forums.fatakat.com/thread2400846 accessed on 8 Sept 2015 7:15 pm CDT):

i love franco chat bs ana ba7eb el 3 arbi akter we 5 sosan fe fatakat msh by7boh

walhy da ana bashed fe shazry lma ala2y w7da ktba topic bel franco ana 3arfa anhom msh by7boh bas a7na bn7bo leh msh nezmel 7aga negmaz bazdena we nozod netklam m3a bazd bel franco el ben 7 bo

7 Information in this section comes from an unpublished paper by Mahmoud Al-Batal. I retain responsibility for any fault in the analysis presented. 
I love Franco chat but I love Arabic more, especially in Fatakat they don't like it. Honestly, I want to pull my hair out when I find someone has written a topic in Franco. I know that they don't like it but we like it. Why don't we do something? We could get ourselves together and talk in the Franco that we love.

What is interesting here, amid the rather chaotic writing patterns, is that many of the short vowels do not appear. The lack of short vowels was one of the reasons cited for the need to reform Arabic script in the mid-twentieth century. Yet, these writers are using a consonantal-based writing system similar to that of fuṣhā. These kinds of writings suggest that the lack of short vowels does not, after all, constitute an impediment to communication. ${ }^{8}$

From this vantage point, we see that the divergence of rhetoric and practice has almost reversed itself from 100 years ago. In the early 2oth century, there was a rhetoric of reform, but the practice was closely controlled, and no reform project was seriously considered. Of the giant thinkers and literary figures who lived and worked in the first half of the twentieth century, only Louis Awad authored an autobiography with some colloquial style, but the 1942 manuscript was not published until 1965 (Doss 2006:55-56). In the early 21st century, there are few calls for reform - metalinguistic rhetoric focuses mostly on standard language ideology and the complaint that Arabic is in danger - but there is a growing practice that is uncontrolled and free-market, and experimenting with form and function. Practice can and does shift language ideology, when it is not under the control of ideology-maintaining institutions.

A culture of standard language ideology, then, is one in which the linguistic ideal carries high cultural value (Milroy 2001:538). This explains Ferguson's observation that every diglossic language has "a sizeable body of written literature in $\mathrm{H}$ which is held in high esteem by the speech community" (1959:238). This is true in part because the value of the literature is enhanced by the cultural value of the ideal language.

8 They are, however, an impediment to reading texts aloud, because short vowels are rarely marked, and the case system is difficult to master. The deep ambiguity among the educated elite toward making Arabic more or less accessible is a topic very much in need of study. 


\section{The Complaint Tradition}

Since the ideal - fuṣhā in our case - is such an important cultural possession, mechanisms exist for both maintaining and legitimizing standard language ideology. Milroy argues that mechanisms and practices that maintain standard language ideology exist in all "standard language ideology cultures," and he calls one of them "the complaint tradition," noting that in English, it is hundreds of years old (2001:538).

The complaint tradition is so developed in Arabic that we may call it a complaint genre, and it has a long history. Beginning in the ninth century CE, we see books emerge that are later called collectively لحن العامة "solecisms of the lower classes." The modern versions of this genre go by the names "widespread errors" and قل "أخطاء شائعة "say (x) and don't say (y)." In the past 40 years or so, more than twenty books with these titles have been published. Nowadays, the internet provides a convenient venue through which to highlight and attempt to correct these "common mistakes;" the chart in figure 2.2 is just one example among many.

Arabic culture takes the complaint tradition a step further than the occasional newspaper article and treatise on "correct usage" that we are all familiar with by utilizing state institutions to "correct" writing. The institution of language correction appears to be a modern institution, born sometime after the birth of the printing press. In view of the absence of any in-depth studies of language correcting in the Arab world, we do not know much about its history or how widespread it is today. Haeri (2003) gives important basic information about Egypt, which shows that this institution is clearly linked with the spread of the printing press, but its widespread presence in publishing and news organizations indicates the pervasiveness of standard language ideology. This link is embodied in Ibrahim al-Yaziji's book, لغة الجرائد (1901), which purports to teach aspiring journalists and writers how to write proper Arabic (1993).

In the 21st century, some language correctors are online, among them one Ahmed Montaser. In the following excerpt from his blog entry titled "The Future of the Profession of Language Correcting," he defends his profession with the use of language that is patently non-standard. From the ämmiyya

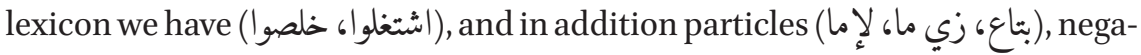
tion (دش)), demonstratives (دية), and relatives (اللية). It is a conversational style,

9 This is a literal translation of the term العامة; as al-Jahiz himself points out already in the 9th century $\mathrm{CE}$, this term refers to those who tried to speak like the elite, but whom the elite wanted to exclude (Bayan wa Tabyin 2:146). 


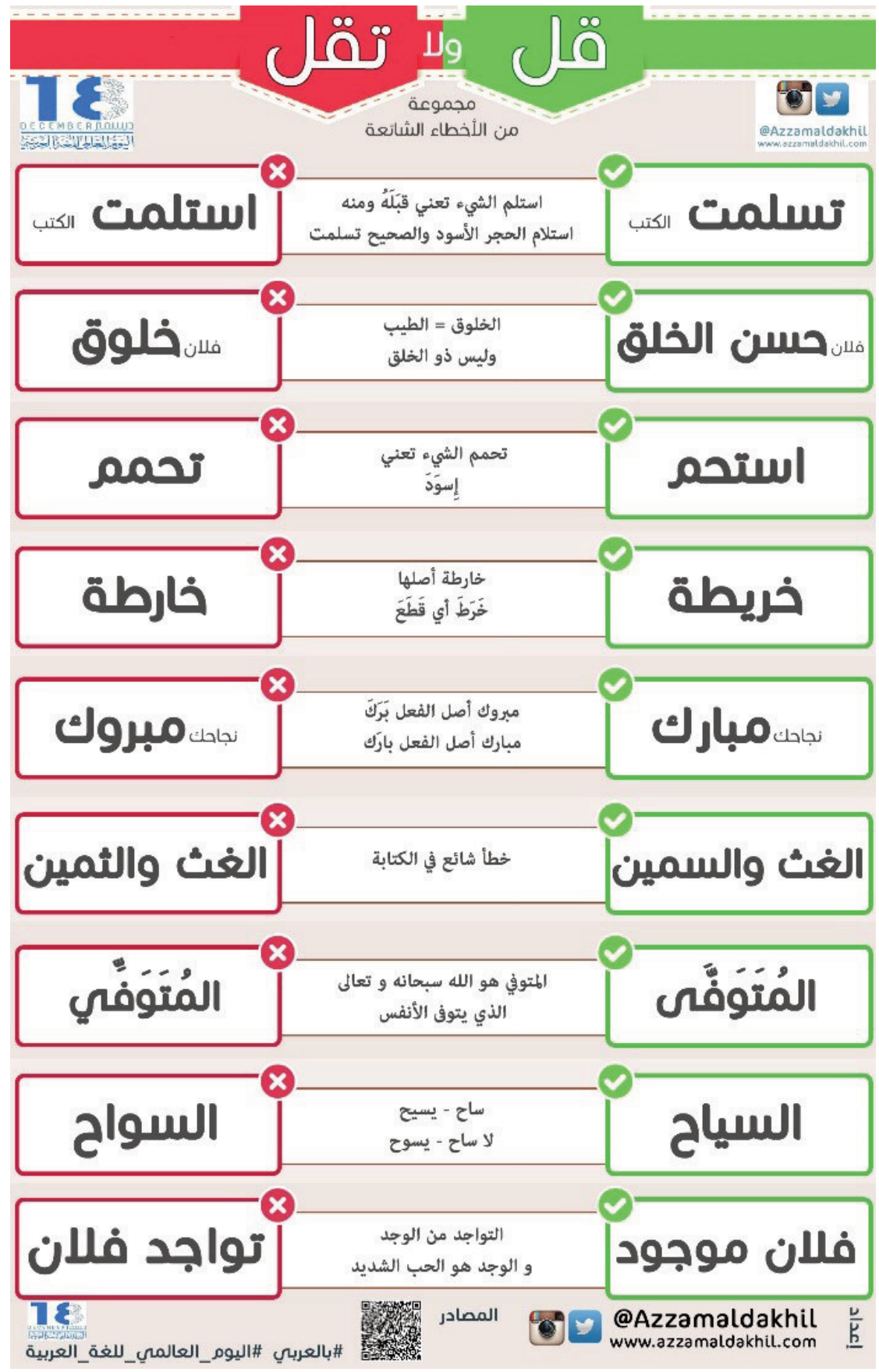

FIGURE 2.2 Internet chart by the International Day of the Arabic Language showing common "mistakes" 


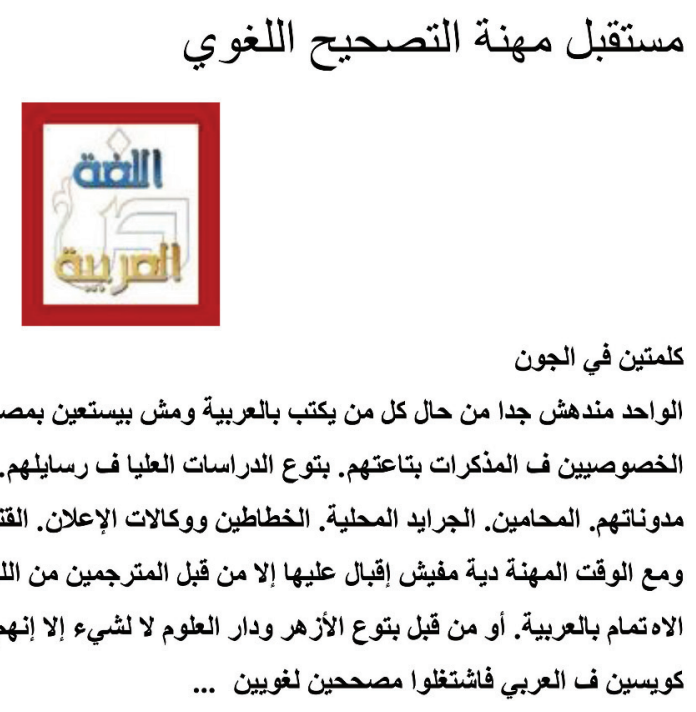

FIGURE 2.3 Blog post by Ahmed Montaser, http://ahmedmontaser.blogspot.com/20o8/o8/blog -post_og.html, accessed on 9/6/2015 10:15 pm cDT

and not unusual for the informal writing on the net. What is striking, however, is the use of this language by a writer whose profession it is to standardize the writing of others. We can understand from this that Ahmed Montaser distinguishes different types of writing, and the fact that he specifies "writers who publish on the net in their forums and blogs" as needing his services, while his own blog is non-standard, suggests that it is not simply a matter of genre.

It is expected that new technologies engender new practices of writing, and computer-mediated technologies constitute a welcoming space for writers to experiment with new forms. This explains in part why non-standard writing is ubiquitous in cyberspace. Even so, this text is of special interest to us because of the relationship of its form to its content. Ahmad Montaser is invested in the importance of the fuṣhā ideal, at least for his own livelihood, yet at the same time does not feel compelled to write in it all the time. His use of non-standard style to defend the profession of language correction suggests that the internet is helping to bring about a reconfiguration of ideologies of writing. He specifies very deliberately the kinds of writing that should be corrected: in addition to the writers' blogs and forums noted above, he includes school texts and review notes, theses and dissertations, legal writing, local newspapers, calligraphers and advertisement agencies, and satellite channels. He apparently excludes his own blog from the category of "writers' blogs," despite the fact that he is a 


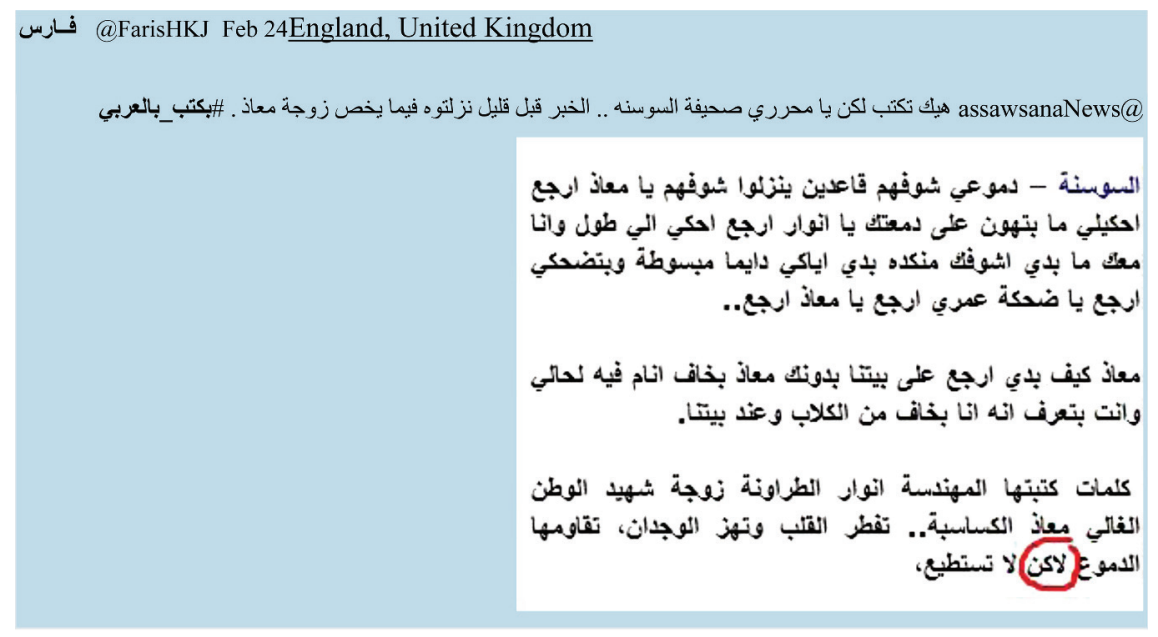

11:54 AM - 24 Feb 2015

FIGURE 2.4 Tweet from the Twitter hashtag \#I_write_in_Arabic

highly sophisticated user of fușha . Since it is his aim to promote the profession of language correction, we may understand his list of "correctable texts" to be the broadest possible list. It is likely that these also represent the contexts in which he notices grammatical errors in writing, a possibility that suggests that writing in 'ämmiyya and making mistakes when writing fușhā are two very different things - perhaps two different kinds of writing. This would mean that the ideology of fuṣha is not threatened by writing in 'ämmiyya - but it is threatened by mistakes in fuṣhā.

This hypothesis is supported by the tweet in figure 2.4 from the Twitter hashtag \#I_write_in_Arabic, in which the tweeter takes an electronic news agency to task for misspelling لاكن but as but though his own tweet and most of the article he cites are both in ámmiyya.

This complaint targets a violation of the spelling standards that this reader expects from the keying that fuṣha $\bar{a}$ triggers in the remainder of this particular sentence. Here too, the language used in writing does not have to be fușhāa but if one is going to use fușha , it should be correct, and have correct orthography. This kind of evaluation suggests that the ideal standard of fuṣhā remains intact, even as it shares writing space with non-fuṣha texts and passages. The internet, therefore, while providing opportunities for free-market variation in written form, also provides opportunities for the kind of evaluative feedback that helps to maintain fuṣhā as an ideal standard.

How then does one distinguish between writing in ämmiyya and writing in error-ridden fușhāe If genre and content are no longer the sole determining 
forces of language style or register, there must be certain clues that help the readers orient themselves and set their expectations. How does Ahmad Montaser's blog clue its readers in to the fact that this is not to be evaluated as 'bad fuṣhă' but rather as an acceptable 'ämmiyya mix (I assume here that all written texts will be a mix of some kind, since the conventions of writing are to a large degree borrowed from fuṣhā)?

Bauman's concept of 'keying,' or setting the stage for a particular kind or genre of performance, helps us think about this question (1977:15 ff.). Although Bauman uses the concept to theorize the characteristics of verbal art performance, keying, or 'setting the stage' for a certain kind of performance, is helpful in analyzing mixed writing. It should be the case, then, that the opening of the text sets the linguistic tone and expectations within which the text is to be read. Here, Ahmad Montaser's use of الواحد is unmistakably 'ammmiyya, and yet its informality is mitigated by the predicate مندهش, which, though it can be read with 'āmmiyya voweling, signals a more formal ( fușhā) register. These two words key the range of language used in the text, and in so doing help the reader key her or his reception of the text. If we analyze the keying of wide array of texts - especially texts published on the internet - it may be possible to find patterns of language use that correspond to particular styles.

This blog suggests that the culture of standard language ideology is shifting, not simply moving away from the ideology that the standard is important even if it is self-serving in the case of Ahmad Montaser - but rather toward an embracing of variation in style, the kind of variation that appears to characterize a significant part of the (unwritten) history of written Arabic.

\section{Language Ideology, Attitudes and Practice}

I have argued that the culture of standard language ideology colored both views and practices throughout the twentieth century, and that the "feelings" and "beliefs" that Ferguson noted and tried to explain constitute a particularly concentrated period of this ideology. But now, in light of new technology that has disrupted the institutional hold on language correction, what is happening to this ideology? We will examine two sets of data: Twitter feed on writing "بالعربي" in Arabic with a hashtag in 'ämmiyya, and the LCAW survey that was carried out in Cairo and Rabat. 


\section{بـ_\# \#__write_in_Arabic}

This hashtag represents a Twitter campaign that was launched in December 2014 in celebration of International Arabic Language Day, December 18. The tweeter who launched it was working as a representative for Samsung Levant, and may have done so as part of her professional responsibilities. The launch invited people to participate in a campaign of writing in Arabic on social media in celebration of this day. The campaign relies on the importance of Arabic to the potential audience, and supposes there will be interest in engaging with the topic. Samsung takes advantage of the economic opportunity to launch a new product, capitalizing on the cultural importance of written Arabic.

The hashtag this tweeter chose for this campaign is: in_Arabic, in the colloquial register of 'ammiyya. Several factors may have played a role in the choice of this register, not the least of which is that it immediately takes off pressure to write in fuṣhā by "keying" the context with colloquial. As we should expect in the case of a new medium for writing, the linguistic styles and registers of the tweets vary widely, and there is no one register that dominates. This variation comes as no surprise; it is axiomatic that writers using new media technologies experiment with language forms and styles (registers), so the widespread use of 'ammiyya forms should not be surprising, especially given that the hashtag itself is in 'ammiyya. But since the topic here is writing, this hashtag is an ideological site that gives us a window on the attitudes and practices of elite youth in the Arab world toward what "writing in Arabic" means, or, perhaps more importantly, what they think it should mean. The attitudes and opinions expressed in the feed are far from uniform.

Responses to this call, as one might expect, varied widely in form and content. Many of the tweets generated in response were pictures of calligraphy or artistic renditions of Arabic letters such as the one in figure 2.5.

Other tweets contributed various types of praise and enthusiasm for the Arabic language, and conformations of the link between language and identity. I found five tweets expressing disdain for "فرانكو" Franco, of which we saw an example above, while other tweeters complained about people thinking it was not "cool" to speak or write Arabic, presumably reflecting pressures they felt in their personal or professional circles. Some of these complaints were oblique, such as the "proof" that Arabic is more powerful than English because it takes seven English words to translate the Arabic word "a-nulzimukumūha". The image in figure 2.6 was repeated in the Twitter feed in various guises.

Tweets are limited in length to 140 characters; therefore, it is likely that some linguistic choices are deliberate. One example of such a choice is a tweet 


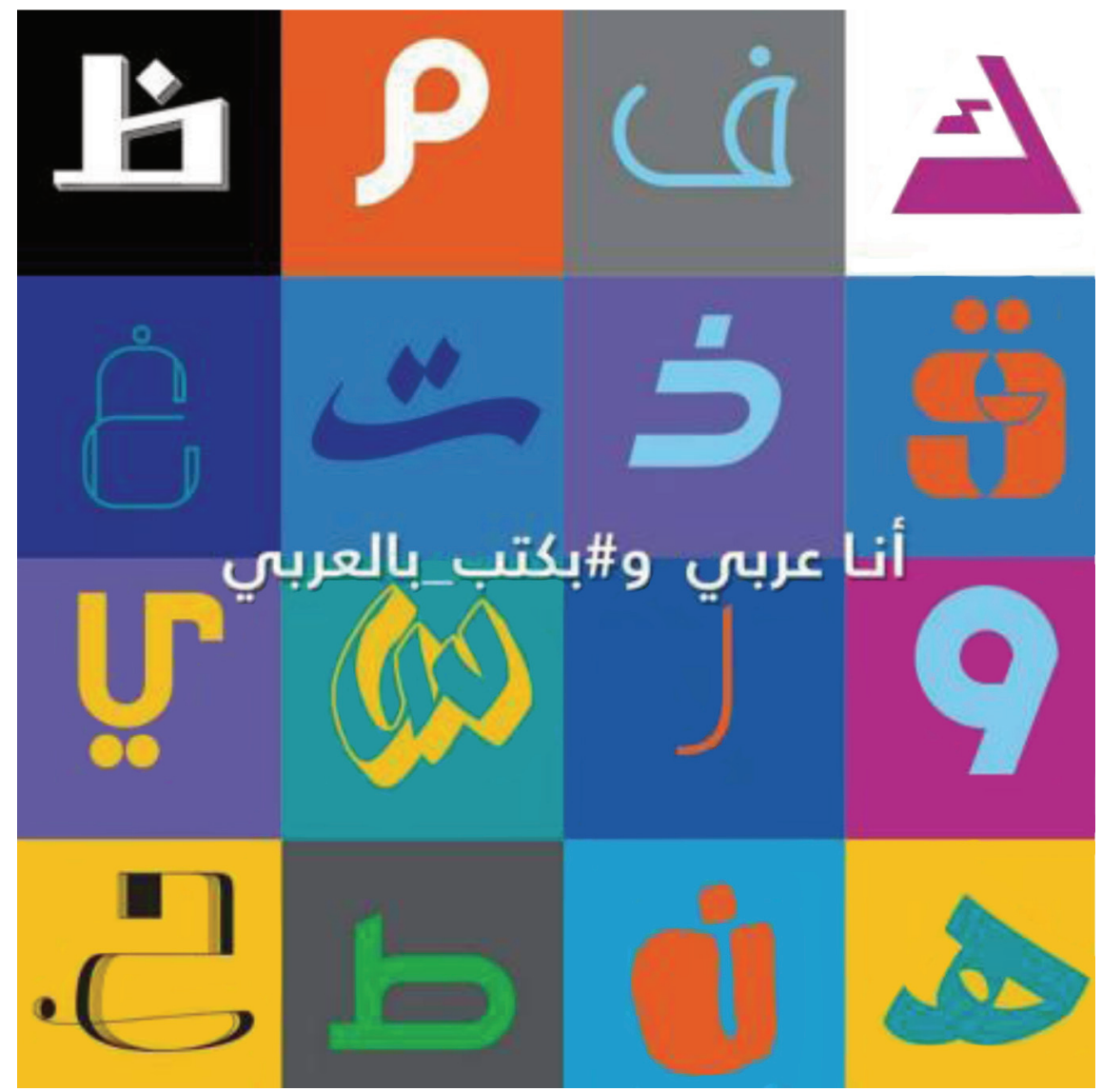

FIGURE 2.5 Tweetfrom the \#I_write_in_Arabic

that was in fuṣhā except for the shortening of على to $\varepsilon$, which is non-standard, except that it may be an abbreviation to save character space. This suggests that this platform may eventually contribute to the development of abbreviations acceptable in formal Arabic. It is also worth noting that subordinate verb phrases and sentence complements require a greater number of morphemes in fuṣha than in 'âmmiyya - in a limited writing platform, it would seem to be a spatial advantage to use 'āmmiyya over fuṣhā.

There were a noticeable number of quotations among the tweets in \#I_write_ in_Arabic. This means that tweeters do not have to compose content themselves, and hence they need not fear committing errors if they want to tweet in fusha - they can retweet or tweet a quote. Thus, there need be no "performance anxiety" over the production of fuṣha , since one can just retweet existing text, which is very common in this hashtag. In fact many of the tweets consist of 


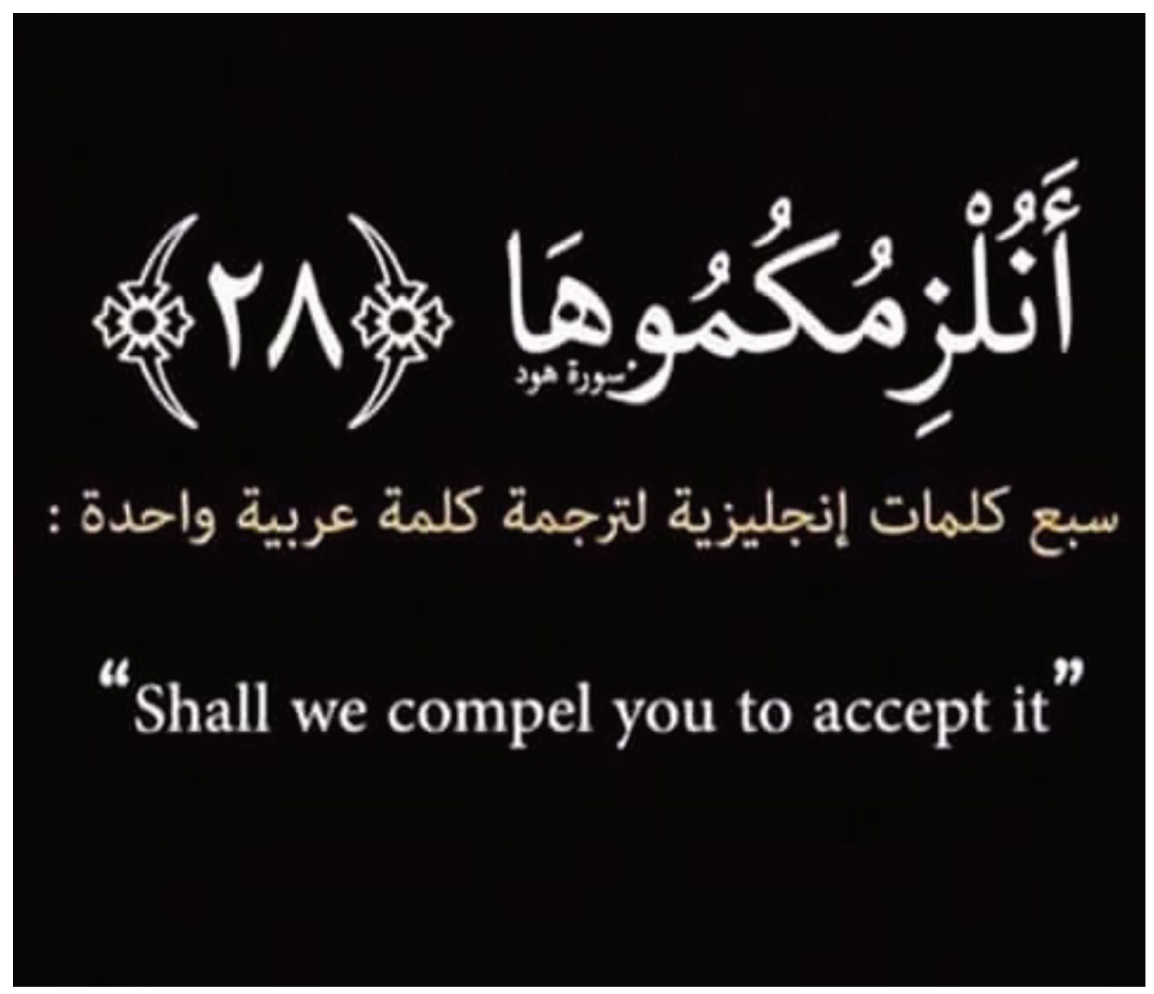

FIGURE 2.6 Tweet from\#I_write_in_Arabic

citations from a variety of sources, including lines of poetry (many quoted the line from Ahmad Shawqi about the language of $d \bar{a} d)$, as well as quotations and sayings from famous figures, including the second Caliph, Umar ibn al-Khattab, who appears many times from at least three independent sources. The important cultural figures from the past serve to reinforce the cultural value of fuṣha over 'āmmiyya, without making an overt link, or even mentioning fuṣhā.

The Twitter feed also includes several resolutions to write in Arabic more often, including this one in 'àmmiyya:

Balqees بقبيس@BalqeesRahil Dec 18:

$$
\begin{aligned}
& \text { لانه بالعربي احلا .. من اليوم ورايح رح اكتب بالعبي واذا كتبت بغير العربي رح ترجم } \\
& \text { للعربي شكرا لكل من ساهم بهالمبادرة }
\end{aligned}
$$

Because it's more beautiful in Arabic ... From now on, I'm going to write in Arabic, and if I write in another language I'll translate into Arabic. Thanks to all who contributed to this initiative. 
About ten days after the hashtag launched there was a spurt of activity commenting on the register of the hashtag itself, for example:

Nouf Alhassan @umdalal100 - Dec 19

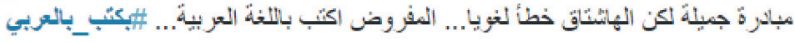

A few ridiculed the choice of 'ammiyya for the hashtag:

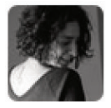

Sara Qudah@_SaraQudah.Dec 21

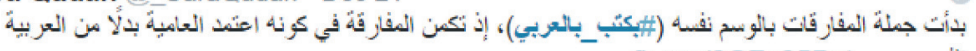

fb.me/2GFq95Pat ..... الفصنى

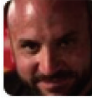

Hussein M. Dajani @hussdajani· Dec 19

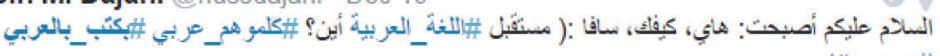

\section{1}

Including one tweeter whose performance of fuṣhā leaves something to be desired:

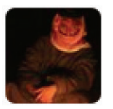

M.G@Mohammed_Gasim -Dec 18

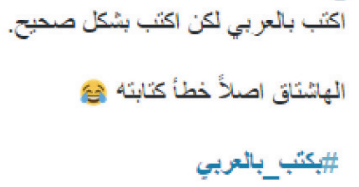

Ironically, not all the complainers used fuṣhā to complain:

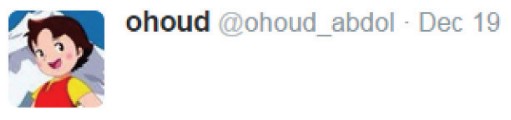

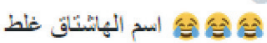

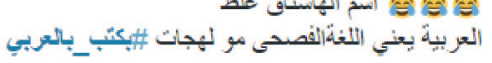

And, a few tweeters supported the freedom to write in 'ämmiyya:

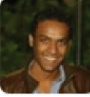

\section{Mohamed Al-aswany @ASAWEEN - Dec 18}

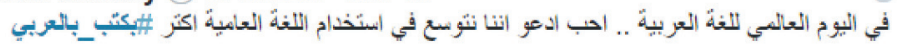


And one appeared to not care very much about fușhāa at all:
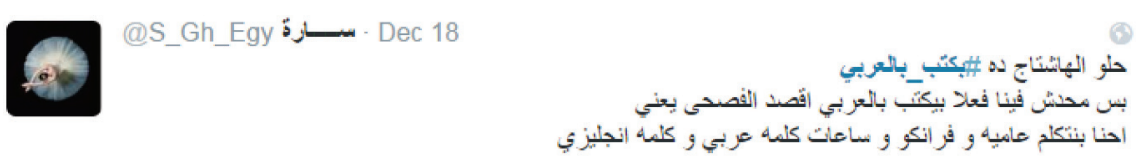

It was interesting to find a tweeter who objected to the practice of spelling first person singular verbs without an alif, but not to writing in 'āmmiyya:
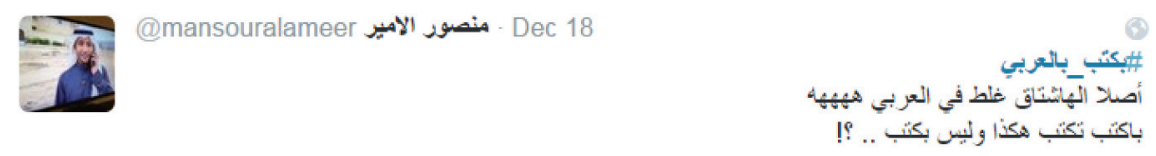

However, a surprisingly small percentage of tweeters during the first month of activity on this hashtag engaged the question of register directly. During that month, there were approximately 9000 tweets in response to the campaign. Of these, only about twenty-five dealt directly with the topic of fuṣha and 'ammiyya. Thus for these participants, engaging in the debate over correctness of register was less important than posting other content. ${ }^{10}$

The few who did comment or ask about language form did so in a variety of ways. A Moroccan tweeter objected to the "eastern" dialect, but corrected to a hybrid form in which the 'ammiyya masculine for Arabic is retained instead of the fuṣha feminine adjective (for lugha), but the imperfective verb is written in fuṣhā form without a prefix:

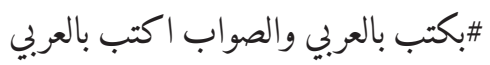

An early tweet asked about the register of the hashtag and requested for clarification:

\footnotetext{
10 I am extremely grateful to my two undergraduate research assistants, Addie Block and Sofia Belarzi, who not only introduced me to Twitter and found this hashtag, but also spent hours combing through the tweets for this statistic.
} 
DدمanaAlBasha Dec 8

$$
\text { اثراء المحتوى العربي؟ لأنه يوجد فؤال: هل الهدف من هاي الحملة هو استخدام الأحرف العربية أم لغة عبية فصحى وعربية عامية }
$$

DanaAlBasha Dec 8

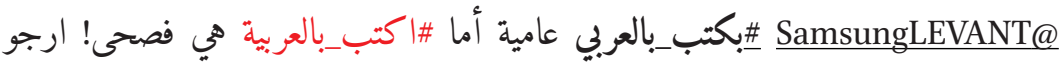

$$
\begin{aligned}
& \text { التوضيح **هاي كتبت سهوا في التغريدة السابقة :) }
\end{aligned}
$$

This tweeter asks in fuṣhā whether the goal is to just use Arabic letters or to add Arabic content to Twitter, since there is a difference between fuṣh $\bar{a}$ Arabic and 'ammiyya Arabic? Then, in a second tweet, she clarifies that the original hashtag is in 'ämmiyya, and gives the fușha equivalent, then offers an indirect apology for her own use of the Levantine 'ämmiyya demonstrative "hay" in her previous tweet. Her inquiry about the intention of the campaign shows that she is not certain of the expectations regarding writing in this context. The immediate reflex to use mixed register in the first tweet (hay) yields by the end of that same tweet to vocabulary of a markedly different style: ithra', to enrich, a literary register. This style-shifting reveals that this writer is keenly aware of multiple audiences and that her tweet is itself a performance for these audiences. It also suggests that the question itself, framed as it is around fuṣh $\bar{a}$ and 'ämmiyya, might require one to demonstrate knowledge of fuṣhā in order to show her qualifications to talk about it - borrowing Bauman's concept of verbal performance, we can call them her performance capabilities (1977:7 ff.). She can use the lexicon and style of fuṣha to claim this license, and part of doing so is pointing out she is aware that the use of "ämmiyya "هاي" was done "inadvertently" (سهواً). This admission and her use of fuṣhā lexical items bring her "performance" of writing in line with fuṣhā standards.

\section{The LCAW Cairo Survey}

In a pointed review of the use of attitude and reported behavior surveys in social sciences, Jerolmack and Khan propose the term "attitudinal fallacy" to refer to their observation that:

Because meaning and action are collectively negotiated and contextdependent, we contend that self-reports of attitudes and behaviors are 
of limited value in explaining what people actually do because they are overly individualistic and abstracted from lived experience.

2014:51

It has long been noted that participants in sociolinguistic studies often display discrepancies between their recorded linguistic behavior and the behavior that they report. Reporting on one of his own (1981) studies in which actual and reported behavior diverged widely, Milroy surmises that these speakers "interpreted the task as a test of their knowledge of the 'correct' pronunciation and responded accordingly: they did not want to be thought ignorant" (1999:16). Both of these observations help us frame this phenomenon within our language ideology framework. While not individualistic, language ideology is highly abstracted from lived, interactive experience, and reflects for speakers the natural state of affairs that they do not think about or question. The LCAW surveys of language attitudes thus provide a good opportunity to explore language ideology in Cairo and Rabat. I propose we assume that the survey results provide reliable information on the participants' understanding of acceptable attitudes in the society around them, whether or not they hold these views themselves.

We will now turn to three areas in which the Twitter feed and the LCAW survey reveal ideological biases: Education and perceptions of fușhā, attitudes toward written 'ammiyya, and reported or actual writing practices. We will begin with education and writing.

\section{Education and Attitudes Toward fuṣhāa and ‘ämmiyya}

Since writing is usually learned at school, attitudes towards Arabic classes deserve attention. Anecdotal evidence, such as interviews reported by Haeri (2003:39 ff.) and the question posed to the little girl in the trailer of the wellknown film Arabizi (https://vimeo.com/1849133, 00:33-00:52), who shyly tells the interviewer that she prefers English class to Arabic, suggests that many students' experience with Arabic language classrooms in school is not a positive one. Thus, we might have expected the survey results from the question, "How well did you like [Arabic] at school?" to be mixed or on the negative end of the scale.

The survey results were surprising. By more than double, more Cairenes reported that they liked Arabic better than mathematics, and by more than triple, they preferred it to science, social studies, and even English. ${ }^{11}$ Rabatis fol- 
lowed suit, although with slightly different percentages: $38 \%$ overall reported a preference for Arabic over all other subjects including French (which was actually third following mathematics). It is particularly interesting that in Cairo, the responses to the questions on Arabic and English stand in mirror image of one another: the highest percentages of responses compare Arabic favorably to other subjects while they compare English unfavorably to them. In Rabat, the questions themselves differed, such that participants were asked to rank their favorite subjects; French sat consistently third in ranking. These unexpected answers can be easily explained in the framework of standard language ideology. Arabic is an important cultural possession, and as such, one is "expected" to like it. As Milroy notes, when answering questions about linguistic behavior, people sometimes give the answer that they feel is the "correct" one.

Reported writing practices in the LCAW survey are abysmally low. Between $83-90 \%$ of respondents in Cairo, and $52 \%$ of those in Rabat, claim not to use (off-line?) writing at all for school assignments. It is not unreasonable to connect the dots: the language of reading and writing that is traditionally taught in schools is a language of evaluated performance. The extent to which formal education increases competence in fuṣhā in Cairo was investigated by Parkinson (1993, 1994), who found that it does to some extent, but that Egyptians' knowledge of fușhā Arabic grammar shows significant gaps even in the ability of those who specialized in Arabic to choose correct case endings on a grammar test - despite the case endings being a focus of language instruction beginning in elementary school and continuing throughout. Parkinson notes that there is a "clash of overt and covert norms and expectations" vis-à-vis fuṣhā (1993:72), and this is our cue that standard language ideology is at play. The overt expectations are for students to learn fuṣha $\bar{a}$ well enough to use it, but the covert expectations may be more ideological in nature: focusing on the case system without actually succeeding in teaching it works precisely to reinforce its ideological status (rather than its actual use).

One of the most revealing parts of the survey for our investigation of language ideology is the set of questions asking respondents to label a set of questions as fușhā or 'ämmiyya. ${ }^{12}$ The sentences were composed and discussed at length by the researchers in the LCAW project. The aim was for them to represent a mix of fușhā, 'ämmiyya, and mixed sentences. Most of the sentences follow the rules of fușhā as understood in the widest sense possible, with some

people who studied in private schools had a significantly lower appreciation for Arabic, reflecting perhaps the stark contrast between the teaching of European languages in these schools and the teaching of Arabic.

See Kindt and Kebede (this volume) for additional discussion of these sentences. 
intentionally ambiguous. In sentences 1 and 6 , the use of feminine singular agreement with the subject الناس people is possible in classical Arabic, but more commonly used in 'ämmiyya. Only sentence 4 is blatantly 'ämmiyya, with an indicative verb prefix not found in fuṣhā. One of the aims of this exercise was to try to see if any syntactic features tended to elicit one response or the other.

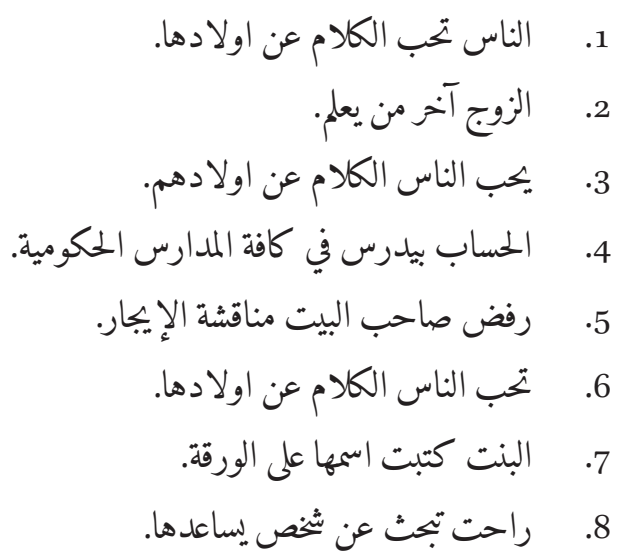

The surprising result was the extent to which not one of the sentences were labeled by a majority of the respondents as fușhā, despite the fact that several of them follow fuṣha rules carefully. Why? I believe the answer begins with Parkinson's aforementioned research in Cairo. First, his findings suggest that very few people have active or productive knowledge of fuṣha grammar. More importantly, though, his experiences suggest that fuṣhā is a performative register in which even those who could not perform "correctly" could nonetheless perform stylistically. For the professional Arabic teacher, fuṣhā is marked by the accurate production of certain rules of grammatical agreement, case endings, and certain lexical items. But to "lay" persons, there may be more important cues, such as rhetorical topic markers and stylized conjunctions فإنّ، فقد and the like. In hindsight, it seems that the absence of these features in the survey sentences may have had an effect on some judgements, especially of the less confident participants.

\section{'Āmmiyya/dārija in Writing}

In the LCAW surveys, results of questions that have to do with attitudes toward fușhāa and 'āmmiyya/dārija in writing largely match the practices we found on Twitter, with the exception that the attitudes of Moroccans surveyed rather 
pointedly disfavor dārija in writing. The most basic question in this regard has to do with the extent to which 'ämmiyya/därija is accepted as a written language. In response to the question, "Do you agree that 'ammiyya/dārija has a place as a written language?", responses varied fairly widely between Cairo and Rabat. In Cairo, we find that over half of those surveyed agreed that 'ämmiyya belongs on the page (35\% "agree," and $22 \%$ "strongly agree"; Kebede et al. 2013:78). In Rabat, the trend is reversed: $58 \%$ of respondents disagreed (to a greater or lesser extent) that dārija belongs in writing. In Cairo, only $20 \%$ disagreed or strongly disagreed that 'ämmiyya has a place as a written language, while in Rabat, that figure for dārija was $32 \%$. These results suggest that standard language ideology still informs what is felt to be the "correct" answer by a significant percentage of the participants, but more so in Rabat than in Cairo. One obvious explanation for this difference is Cairo's long history of writing in 'āmmiyya (Doss 2006, Doss and Davies 2013).

To what extent are the more educated parts of society invested in maintaining fuṣha as the language of writing? More in Rabat than in Cairo, according to survey results. In general, more of the higher-educated disagreed, and fewer agreed, that 'âmmiyya/dārija has a place as written language. These results are not surprising; if anything, the surprise is that the differences are rather small, especially in Cairo, where only 4 percentage points separate the least and most educated who strongly agreed that âmmiyya belongs in writing. In Rabat, the differences in education are a bit more pronounced: $67 \%$ of university-educated respondents disagreed that dārija has a place as a written language while only $50 \%$ of preparatory-educated respondents disagreed. Socio-economic percentages largely echo the education results, assuming that the most highly educated also tend to self-report being in the top socioeconomic group.

At the same time, educated Cairenes are not invested in maintaining fuṣha as the only written register. As a group, those surveyed disagree with the statement that 'ämmiyya is unsuitable as a written language (Kebede et al. 2013:71). These results strongly suggest that acceptance rates for writing in âmmiyya rise among the more highly educated and better-off economically. This is to be expected because, as the results show, 'ämmiyya is accepted widely on the internet and in social media, reflecting the social communicative functions of 'ämmiyya quite well. In Rabat, on the other hand, more than half disagreed that "dārija has a place as a written language," despite self-reported practices of using dārija to write in texts and on social media. This disconnect suggests a stronger standard language ideology in Rabat than in Cairo. It may also be a function of the relatively widespread use of French in writing on social media and in the workplace. 
Turning again to Ahmad Montaser's blog on the profession of language correcting, it helps us make sense of the attitudes and practices connected to writing that we find in the survey. In Montaser's blog the form of the language that he uses is dissociated with the content. This decoupling is one of the keys to understanding what is happening ideologically. It is not just that someone whose job it is to produce correct Arabic participates in the discourse that is public and nonstandard; it is also the fact that the message that he provides in this blog reinforces the importance of the standard. It seems that, for this blogger, as long as the importance of the ideal standard is not challenged, it does not always have to be maintained. Standard language ideology is not disappearing, but it no longer dominates public writing spheres, and may be losing its connection with the ethics of public behavior.

The public sphere is not so much a thing (community) as a process (interacting). Leaving aside for now the fact that the internet remains inaccessible to the poor, new communities in cyberspace are coming into being outside the control of traditional social, economic, and political institutions and powers. Of course, the scene is ripe for struggles of power, and this is something to watch as we move forward. It is no accident that Samsung launched its hashtag in non-standard Arabic: By keying the communicative, interactive registers of Arabic, they hoped to get more people involved and interacting. The economics of 'âmmiyya assert themselves here, as they have already done in traditional broadcast media, in commercials on radio and television.

In the history of writing with non-standard forms, the use of such forms recognizable as representing speech are a kind of stylistic performance on the part of the writer. What is happening now may be seen in part as a similar phenomenon, except that more writers today are performing their own multivalent social identities, rather than literary ones. Future study of writing needs to explore the relationship of artistic styles to non-artistic styles, and the use of 'crossing' as an artistic or performative device. We cannot talk about the sociolinguistics of writing without acknowledging the role of the performers of written language. Educated people have spent longer, and had more direction and training and tools, for how to perform.

Finally, it is crucial to remember that this is not a zero-sum game: more writing in ámmiyya does not necessarily mean less writing in fuṣhā. The LCAW Cairo survey reports: "Among those with university education, 30 percent write in fușhā everyday whereas only 12 percent of those with preparatory education report the same $\ldots 42$ percent of university graduates write in 'ämmiyya everyday while only 26 percent of those with preparatory school report the same" (Kebede et al. 2013:94; Kindt and Kebede this volume). Thus, according to people's reporting of what they do, it is not the case that the educated elite write 
more in fușha than they do in 'ämmiyya while the less educated write more in 'ammiyya. Rather, it is the case that educated Cairenes report writing more regardless of the language register.

\section{Conclusion}

I have argued here that the concept of diglossia is useful primarily as a language ideology, and in the case of Arabic, it can be seen to have arisen during the nahda and, due in great part to its pride of place in Arab nationalism and its usefulness in censorship through the offices of language correctors, was promoted throughout much of the twentieth century. Seen in this light, the explosion of writing in 'ammiyya/dārija suggests that the reign of standard language ideology as the most powerful language ideology in Arabic culture is on the wane.

However, even if this were so, it would not mean that fușhā is in danger of slipping away. It is true that the Qur'an has played an important role in the maintenance of fușha as the standard ideal, but that would not have been enough to keep it alive for over a millenium. What has kept fuṣha alive all these centuries is precisely its symbiotic relationship with âmmiyya, which provides it with the stuff of social intercourse, human communication and emotion. Fuṣhā, on the other hand, provides 'ämmiyya with a rich body of material lexical, phonological, and morphological - that allows it to stretch beyond its everyday functions into the realm of the artistic, a process which in turn helps bind it with fuṣhā. Fuṣhā acts as do the performance registers in other languages, stretching the boundaries of expression, providing models and inspiration, and linking speech communities across time and space. The ideology of diglossia obscures this deep and lasting relationship. More ámmiyya and more fuṣhā go hand-in-hand, and mean more written Arabic for all.

\section{References}

Al-Jallad, Ahmad. 2015. An Outline of the Grammar of Safaitic Inscriptions. Leiden: Brill. Ayoub, Georgine. 2011. "Fașịh." Encyclopedia of Arabic Language and Linguistics, edited by Kees Versteegh, Mushira Eid, Alaa Elgibali, Manfred Woidich, and Andrzej Zaborski, Vol. 2: 84-9o. Leiden: Brill.

Bauman, Richard. 1977. Verbal Art as Performance. Prospect Heights, IL: Waveland Press.

Blau, Joshua. 2002. A Handbook of Early Middle-Arabic. Jerusalem: Hebrew University. 
Brustad, Kristen. 2016. “The Iconic Sibawayh." Essays in Islamic Philology, History and Philosophy. Studies in the History and Culture of the Middle East 31. Berlin: Walter deGruyer.

Dayeh, Jean. 1984. "Bakurat al-Jam'iyyat al-Thaqafiyya fi Suriyya wa al-Alam al-Arabi." Fikr 8 (6o/61): 173-181.

Doss, Madiha. 2006. "Cultural Dynamics and Linguistic Practice in Contemporary Egypt.” Cairo Papers in Social Science 27(1/2):51-68.

Doss, Madiha and Humphrey Davies, eds. 2013. Al-āmmiyya al-Misriyya al-Maktuuba. Cairo: GEBo.

Haeri, Niloofar. 2003. Sacred Language, Ordinary People. New York: Palgrave.

Hanna, Nelly. 2003. In Praise of Books. Syracuse: Syracuse U. Press.

Hopkins, Simon. 1984. Studies in the Grammar of Early Arabic. Oxford: Oxford U Press. Al-Jahiz. 2002. al-Bayan wa al-Tabyin. 3 vols. Cairo: Dar Maktabat al-Hilal.

Tewodros Aragie Kebede, Kristian Takvam Kindt and Jacob Høigilt. 2013. Language Change in Egypt: Social and Cultural Indicators Survey. A Tabulation Report. Oslo: FAFO.

Lentin, Jérôme. 1997. Recherches sur l'histoire de la langue arabe au Proche-Orient à l'époque moderne, thèse de doctorat d'État, université de Paris III.

Lentin, Jérôme. 2011 (2008). "Middle Arabic", in Encyclopedia of Arabic Language and Linguistics, Managing Editors Online Edition: Lutz Edzard, Rudolf de Jong. Consulted online on 23 April 2017.

Lentin, Jérôme and Jacques Grand'Henry (éd.). 2009. Moyen arabe et variétés mixtes de l'arabe à travers l'histoire. Louvain-la-Neuve: Peeters.

Mejdell, Gunvor. 2016. "Erasing boundaries in contemporary written mixed Arabic" in Lentin, Jérôme and Jacques Grand' Henry (eds.): From Legal Documents to TV.and Internet through Novels: Middle and Mixed Arabic across Written and Oral Genres. Louvain-la-Neuve: Peeters 2016.

Milroy, James. 2001. "Language Ideologies and the Consequences of Standardization." Journal of Sociolinguistics 5(4):530-555.

Milroy, James and Lesley Milroy. 1999. Authority in Language: Investigating Standard English. New York: Routledge.

Parkinson, Dilworth. 1993. “Knowing Arabic." Perspectives on Arabic Linguistics 5:47-74. Philadelphia: John Benjamins.

Schieffelin, Bambi, Woolard, Kathryn, and Kroskrity, Paul, eds. 1998. Language Ideologies: Practice and Theory. New York: Oxford University Press.

Zack, Liesbeth and Schippers, Arie (eds.). 2012. Middle Arabic and Mixed Arabic: Diachrony and Synchrony. Leiden: Brill. 